\title{
Competitiveness of health facilities - accounting and analytical approach
}

\author{
Viktoriia Vovk', Svitlana Levitska', Anna Łukasik², Jarosław Ostrowski ${ }^{3}$, Katarzyna Gawęda ${ }^{3}$ \\ ${ }^{1}$ National University of Water and Environmental Engineering, Ukraine \\ ${ }^{2}$ Medical Center for Postgraduate Education, Warsaw, Poland \\ ${ }^{3}$ NZOZ Diagnostics Kutno, Poland
}

Vovk V, Levitska S, Łukasik A, Ostrowski J, Gawęda K. Competitiveness of health facilities - accounting and analytical approach. Med Og Nauk Zdr. 2018; 24(3): 176-183. doi: 10.26444/monz/95135

\section{Abstract}

Objectives. The aim of the study is to investigate the practice of repports of Ukrainian health care institutions on indicators of efficiency described in the brief of target-oriented budget programmes, as well as to identify the level competitiveness in the health care system in Ukraine compared to health care systems in Poland and Russia, by using the above indicators. Materials and method. The legislative Acts as well as statistical data obtained from the European database 'Health for All' were used as research materials. The descriptive method, the method of generalization, the method of ranks, and the systemic, comparative and statistical types of analysis were used as the main methods of research.

Results. Regarding the level of competitiveness of the healthcare system, it was established that Poland had the highest rates according to the criterion of minimum points. The next was Ukraine, followed by Russia. The efficiency and quality indicators played a significant role for Poland. The product indicators were the lowest for Russia.

\section{Conclusions.}

1) Implementing integrated reporting is recommended, which would generalize the evaluation of the effective indicators of the implementation of State medical target programmes as one of the important factors for the competitiveness of direct medical institutions.

2) It is necessary to reform the accounting of national medical units (as part of State policy), based on the accounting principles in accordance with national accounting standards in the public sector.

3) At the State level, Ukraine should pay attention to indicators that are not high enough in comparison with the leading positions of the Polish health system, namely, indicators of efficiency and quality.

\section{Key words}

competitiveness of health facilities, health care institutions performance, integrated reporting, analysis and assessment of competitiveness level, ranking of indicators

\section{INTRODUCTION}

Nowadays, increasing companies' competitiveness is one of the most important issues facing the economy. Since the ability to compete with the manufacturers of the similar production at the market is a rather difficult task, which includes both, satisfying the needs of your consumer and providing efficient financial and economic activity.

Market condition and its regular redistribution depend on the competition results of all participants. Given to this, the companies constantly analyze their weaknesses and strengths in order to assess their true abilities under competitive environment as well as to develop a set of measures, which will allow them to increase their own competitiveness and take over targeted market sector [1].

Under market economy, increasing competitiveness of the national economy in general and a company in particular is an important condition for country's integration into global economy. The higher global competitiveness indicator is, the more capable the country is to provide its citizens with high standard of living, and the more efficiently it uses the resources available. Under free market economy you need

Address for correspondence: Viktoriia Vovk, National University of Water and Environmental Engineering, S. Bandery 40, M.12, 33014 Równe, Ukraine

E-mail:vicnikka@gmail.com

Received: 13 July 2018; Accepted: 14 September 2018 concerted practice and focused effort of all economy sectors to stay at the market. The health sector is no exception.

\section{OBJECTIVES}

The aim of the study is to investigate the practice of reports of the Ukrainian health care institutions on indicators of efficiency described in the brief of target-oriented budget programmes, as well as to identify the competitiveness level of health care system in Ukraine, compared to health care systems in Poland and Russia by using such indicators.

\section{MATERIALA AND METHOD}

The condition of the th care system in Ukraine, defined in terms of financial and statistical reporting indicators of health care institutions is investigated in the study. Analysis of indicators is described in the international qualification system of World Health Organization (WHO) and is also taken into account. For evaluation of the indicators for the of the system for public target-oriented programmes (described in the program brief), the regulatory and legislative Acts of Ukraine have been examined.

The indicators for the efficiency of health facilities from different countries that were the basis for the calculations in 
the study were based on the data of the European database 'Health for All'. This database is posted on the website of World Health Organization and brings together the indicators that are part of major monitoring frameworks. The indicators cover basic demographics, health status, health determinants and risk factors, as well as health care resources and expenditures, among many others. This is why the indicators presented in this study and were selected from this database, most fully allow us to examine the situation in the three regions investigated: Ukraine, Poland and Russia.

Descriptive and generalization methods were applied in the study, when characterizing indicators of efficiency of public target-oriented programmes, along with describing the areas of Ukrainian health facilities enumeration system: comparative and statistical analyses and a generalization method were applied when researching assessment indicators of health care system in the three investigated countries. The ranking method was applied for assessing the level of competitiveness of the health care systems; this allowed comparison of assessments in the group of countries, and to define the place of each one in the investigation. The method did not include fundamental mathematical calculations, but it was suitable for assessing leading country's position in the performance results of health facilities in Ukraine, Poland and Russia.

\section{RESULTS AND DISCUSSION}

Generally, competitiveness is a global concept which can be applied for any market of goods and services. However, every field of economy has its own features, which affect specific development of competitive environment within a particular field. The same happens in the health care area.

Many domestic and foreign researches $[2,3,4,5,6,7,8]$ are devoted to competitiveness; however, in the opinion of the authors, the most successful concept of competition in healthcare was characterized by E. O. Tohunov, who claimed that: 'competition in health care is the condition and process of relationship between the subject of manufacture or consumption of medical services, within a specific reasonable form of competition, and health care personnel (physicians) after achieving the highest level of the patient's target needs satisfaction' [9]. In other words, when describing the level of competitiveness in health facilities, patient's target needs (i.e direct consumers of the given service) play the most important role, which is similar to all other fields of the economy. Ryszard Rotaub supports this position, noting that: 'medical services have their specificity resulting from the fact that they save human life. That is why the health market is specific and differs from the typical free market' [10]. Despite the relative similarity in the definition of the concept of competition, the medical field (under private health care services) has its own specific features of developing a competitive environment:

1. Health care service prices are not always regulated by the market laws via ordinary balance between demand and supply of services. Prices are often high, even if the demand for a certain type of service is high.

2. The right for a health service, declared by the Constitution of every country, stipulates providing public access to health service for all citizens, regardless of the cost of equipment and technologies being used. Thus, the laws of free market are again ignored.
3. There will always be a demand for health service (despite its high cost), since patients will always need treatment, even if they lack the money to pay for it.

4. Implementing innovations into a health care system does not influence market development and a further drop in the price of health service.

5. Low quality of health service will not result in reduction in the number of patients applying to hospitals, even if they had a negative experience before.

According to Michael E. Porter, the features of the medical field will also be reflected in the principles of Value-Based Competition [11]:

1. The focus should be on value for patients, not just lowering costs.

2. There must be unrestricted competition based on results.

3. Competition should centre on medical conditions over the full cycle of care.

4. High quality care should be less costly.

5 . Value is driven by provider experience, scale, and learning at the medical condition level.

6. Competition should be regional and national, not just local.

7. Information on results and prices needed for value-based competition must be widely available.

8. Innovations that increase value must be strongly rewarded.

The funding system of health facilities is especially important. At the moment, the funding in Ukraine is provided by the Treasury of Ukraine, local budgets, health insurance funds, charitable funds, or other sources which are not prohibited by the legislation [12]. State policy of health facilities development stipulates support for the search for other sources of funds, such as charity insurance payments, private services, compensatory payments, etc. [13].

There are two models of health care funding used in developed countries:

- the first is public funding provided by the Treasury. This is used in the United Kingdom, Canada, Italy, Austria, and Ukraine;

- the second is a mixed public and insurance funding but only target-oriented programmes are covered. Health service for socially disadvantaged groups (pensioners, children, students, disabled) is covered by the State and local authorities. Companies and institutions cover the cost for their employees. This is used in Finland, Sweden and Norway, where the State covers $70 \%$ of all expenditures on health service, in the USA - up to $50 \%$. This model is also used in Poland and Russia [14].

Unfortunately, today the activity of health facilities still has a long way to go: services based on competitiveness are not developing, the indicators of efficiency of the facilities are not properly considered when providing funding, and managers are not informed about the assessment of patients' satisfaction level with the services received. This calls for a reassessment of the health care system and development of new national standards which, primarily, will allow assessment of the efficiency of the performance of facilities, their competitiveness, and describe the results achieved in standard reporting forms.

A typical world practice is the unification of indicators for using any external target benefits with the common system of financial accounting and government institutions' 
reporting (including health facilities). For this purpose, there are standardized forms of integrated reporting for health facilities [15]; however, at the moment, there are no implemented forms of Integrated reporting for health facilities in Ukraine, but the indicators of an efficiency system for public target-oriented programmes (described in the programme brief) has been approved. Indicators of efficiency are divided into groups [16]:

1. Expenditure indicators, defining the amount and the pattern of funding that provide budget programme performance - funding from the Treasury to perform certain target-oriented programmes of health facilities.

2. Product indicators, used to assess achieving the goals - the number of consumers for health services.

3. Efficiency indicators, defined as the relation of the services provided with their monetary or human resource cost (resources spent on a unit of product indicator).

4. Quality indicators, illustrating the quality aspect of the services provided.

Analysis of reporting practice for applying indicators approved in the brief of target-oriented budget programmes in national health facilities allowed generalization of the main efficiency indicators (Tab. 1) [17].

The above-mentioned indicators are disclosed to public in financial and statistical reporting on the health facility. Unfortunately, today such reporting forms do not contain all efficiency indicators, for this reason, it is appropriate to implement Integrated reporting. Considering international practice of its implementation, the subjects will be able to show the connection between management, financial results and social, ecological and economical area of activity.

There is no standard form of integrated reporting. However, International Integrated Reporting Council has developed fundamental principles that should be taken as the basis when reporting.

At the moment, national State health facilities have difficulties with describing indicators of expenditures, product, efficiency (calculated measurements), given in monetary units, on bookkeeping accounts, and in forms of financial reporting. It is stipulated by the State policy for introducing the principles of the National Public Sector Accounting Standards (NPSAS), which does not contradict international accounting practice in governmental institutions (including issues of public funds accounting) [18].

Table 2 describes generalization of the most important changes characterizing the accounting health facilities in Ukraine (budget funded activities).

Analytical assessment of the health facilities' efficiency indicators should first of all be based on the data of the standard forms of integrated reporting. This will not only allow comparison of the efficiency of one health facility in Ukraine, but will also enable comparative assessment of health facilities in different countries. This comparison would help health facilities to assess their competitive advantage on internal and external markets, which could promote medical tourism.

At the moment, aggregated indicators on efficiency of health facilities from different countries are fully presented in the European 'Health for All' database [24]. However, considering the specific performance of health care systems in different countries, in the current study, only the most representative indicators for analytical assessment have been selected. The indicators characterize the results of budget programme performance and are supported by reports, such as product indicators, efficiency indicators and quality indicators. Based on the data given by the WHO Regional

\begin{tabular}{|c|c|c|c|}
\hline Name of facility & Product indicators & Quality indicators & Expenditure indicators \\
\hline \multirow{9}{*}{$\begin{array}{l}\text { Health care } \\
\text { centres }\end{array}$} & \multirow{2}{*}{$\begin{array}{l}\text { Number of medical personnel in the facility } \\
\text { (persons) }\end{array}$} & Number of physicians: employed full-time, (persons) & \multirow{3}{*}{$\begin{array}{l}\text { Amount of funding provided } \\
\text { by the budget to manage the } \\
\text { facility, including main funding } \\
\text { items (thousands, hrn.)* } \\
\text { *Hryvnia - Ukrainian currency }\end{array}$} \\
\hline & & $\begin{array}{l}\text { Number of medical personnel: nursing personnel, paramedical } \\
\text { personnel (persons) }\end{array}$ & \\
\hline & $\begin{array}{l}\text { Number of departments functioning on complete } \\
\text { budgetary funding (units) }\end{array}$ & Age range for patients in a clinical setting (age) & \\
\hline & Number of house-calls (times) & $\begin{array}{l}\text { Number of house-calls: by the type of calls, to adults, to children } \\
\text { (times) }\end{array}$ & \multirow{6}{*}{$\begin{array}{l}\text { Amount of funding provided } \\
\text { by the budget to manage the } \\
\text { facility, including the main } \\
\text { funding items (thousands, } \\
\text { hrn.) }\end{array}$} \\
\hline & $\begin{array}{l}\text { Number of patients discharged from inpatient } \\
\text { department (persons) }\end{array}$ & Discharged from inpatient department (persons) & \\
\hline & $\begin{array}{l}\text { Number of surgeries in the inpatient department } \\
\text { (times) }\end{array}$ & $\begin{array}{l}\text { Surgery work: type of operations, surgical result (descriptive and } \\
\text { analytical information) }\end{array}$ & \\
\hline & Hospitals (units) & Acute care hospital discharges (person) & \\
\hline & Hospital beds (units) & Average length of stay, acute care hospitals only (number of days) & \\
\hline & Proportion of physicians working in hospitals (\%) & Average length of stay, all hospitals (number of days) & \\
\hline \multirow{6}{*}{$\begin{array}{l}\text { Dispensary } \\
\text { health units }\end{array}$} & \multirow{2}{*}{ Number of medical personnel (persons) } & $\begin{array}{l}\text { Number of physicians with classification category: higher, } 1^{\text {st }}, 2^{\text {nd }} \\
\text { (persons) }\end{array}$ & \multirow{2}{*}{$\begin{array}{l}\text { Amount of budget funding } \\
\text { for one year maintenance, } \\
\text { including the main funding } \\
\text { items (thousands, hrn.) }\end{array}$} \\
\hline & & $\begin{array}{l}\text { From the total amount of doctors: retirement age physicians } \\
\text { (persons) }\end{array}$ & \\
\hline & \multirow{2}{*}{$\begin{array}{l}\text { Number of patients on follow-up care in a one } \\
\text { year period (persons) }\end{array}$} & $\begin{array}{l}\text { Number of patients on follow-up care suffering from cancer, } \\
\text { active tuberculosis, HIV infection (people) }\end{array}$ & \multirow{4}{*}{$\begin{array}{l}\text { Amount of budget funding for } \\
\text { certain budget programmes, } \\
\text { including main funding items } \\
\text { (thousands, hrn.) }\end{array}$} \\
\hline & & Reduction in the burden of disease (\%) & \\
\hline & Estimated life expectancy (years) & Level of detecting disease at early stage (\%) & \\
\hline & General practitioners (person) & Reduction in lethality rate (\%) & \\
\hline
\end{tabular}


Table 2. Reformation areas for national health facilities accounting

\begin{tabular}{|c|c|c|c|}
\hline \multirow{2}{*}{ No. } & \multirow{2}{*}{ Economic activities } & \multicolumn{2}{|l|}{ Accounting and reporting description } \\
\hline & & considering regulatory accounting base valid until 2017 & considering valid principles of NPSAS \\
\hline 1. & Revenue recognition & $\begin{array}{l}\text { Budget funding recognized as a revenue for the given } \\
\text { period }\end{array}$ & $\begin{array}{l}\text { Revenue is recognized as gross returns of economic benefit or as utility } \\
\text { potential within the reporting period, when net assets/owner's equity } \\
\text { increase due to these returns but not owners' investments [19] }\end{array}$ \\
\hline 2. & Inventory revaluation & $\begin{array}{l}\text { Revaluation conducted if book value of inventory is not } \\
\text { equal to their fair value (agreed with the treasurer) }\end{array}$ & $\begin{array}{l}\text { Inventory valued at the lowest from two valuations: production cost or net } \\
\text { realizable value [20] }\end{array}$ \\
\hline 4. & $\begin{array}{l}\text { Production cost } \\
\text { identification of } \\
\text { depreciated inventory }\end{array}$ & $\begin{array}{l}\text { Production cost of depreciated inventory can be } \\
\text { identified by book value if the inventory is not } \\
\text { interchangeable, otherwise weighted average value is } \\
\text { used }\end{array}$ & $\begin{array}{l}\text { Product cost of non-interchangeable inventory units is identified by using } \\
\text { specific identification of their individual cost for different types or usage } \\
\text { of inventory, production cost formulas can be applied: «first in - first out» } \\
\text { (FIFO) or the formula of weighted average value [20] }\end{array}$ \\
\hline 5. & $\begin{array}{l}\text { Correction of the sums, to } \\
\text { illustrate events after the } \\
\text { date of balance }\end{array}$ & Never conducted in the accounting of health facilities & $\begin{array}{l}\text { The sums, given in the financial reports for describing important events } \\
\text { that occurred after the reporting date, are corrected. If the events show the } \\
\text { conditions present on the day of preparing the report [22] }\end{array}$ \\
\hline 6. & $\begin{array}{l}\text { Accrual of depreciation of } \\
\text { the fixed assets }\end{array}$ & $\begin{array}{l}\text { Depreciation is accrued at the end of the year at a fixed } \\
\text { percentage from the cost of a certain group of the fixed } \\
\text { assets, regardless of the maintenance period }\end{array}$ & $\begin{array}{l}\text { Value of depreciated fixed asset is divided regularly, during the period of } \\
\text { its operation and maintenance [23] }\end{array}$ \\
\hline
\end{tabular}

Source: independently processed

Office for Europe, it is impossible to describe the fourth group - expenditure indicators - since these indicators are incomparable from absolute measurement perspective, thus they are not given in the aggregated statistical data.

Table 3 presents the comparative assessment of health system efficiency in Ukraine and health system efficiency in Poland and Russia, five years apart, for the period of 20 years.

Analysing the dynamics of indicators from the 'product indicators' group, it can be seen that life expectancy in all three countries has been increasing for the last 15 years, which is positively assessed. In 2015, life expectancy increased by 3.8 years in Ukraine and Poland, and by 5.5 in Russia, compared to 2000 , a base year (the indicator is not presented in the reports of all three countries for 1995).

The level of tangible security in health facilities in Ukraine and Russia is deteriorating. Since the goal is to provide hospital treatment, this service can be ensured only with special equipment and tools which are an essential part of the manufacturing process. The provision of hospitals and hospital beds in these countries has dropped twice in the last 20 years. In 2005, the number of Ukrainian hospitals was four for 100,000 people; in 1995 , it was 7.2 which is only $55.6 \%$. In Russia, this ratio is even worse - in 1995 there were 7.8 hospitals for 100,000 people, and in 2015 the number dropped to 3.5 hospitals $(44.9 \%)$. Similar negative phenomena can be observed for hospital bed provision. Positive changes can be seen only in Poland, where the number of hospitals grows every year (in 1995, there were 1.9 hospitals for 100,000 people, and in 2015 - 2.8 hospitals). Although the number increases, it is still lower than in Russia or Ukraine in 2015.

Staffing plays an important role in the assessment of health facilities. Statistics shows that the number of general practitioners (usually practitioners or family practitioners) as well as the number of licensed and qualified physicians providing medical service is the lowest in Poland. Approximately half of these physicians work in hospitals. In Ukraine, there are nearly 300-500 general practitioners for 100,000 people, and are responsible for providing a continuous medical service. Moreover, $90 \%$ of practitioners work in hospitals. The biggest number of general practitioners is in Russia. Staffing evaluation in the health care system can be assessed differently, on the one hand, a sufficient number of qualified physicians for the country's population give the guarantee for the correct treatment. On the other hand, a doctor's salary is higher than that of the nursing staff, which can influence negatively on the cost of a medical service. In developed countries, the nursing staff and physicians ratio is $4: 1$ [25].

The level of public-sector health expenditure as a percentage in all three countries of base period was a little more than $70 \%$. However, only Poland managed to keep the stable level of this indicator, while for Ukraine and Russia in 2015, health care expenditure in the public sector and total health care expenditure ratio was $2 / 3$ from the base period number. This means that the population covers the cost of its own medical service.

The indicator of total inpatient expenditure as a proportion of total health expenditure shows current (excluding investment/capital expenditure) expenditure on inpatient facilities (including public and private hospitals) to treat acute and chronic disease. The level of this indicator in Poland in 2000, 2005 and 2010 was nearly 30\%, whereas in Ukraine, since 1995 the indicator has been dropping constantly from $82 \%$ to $32.26 \%$ in 2010 . The reason for such drop can be a funding shortage for the health facilities, redirecting the expenditure to the patients themselves, and the tendency of patients to choose ambulatory (cheaper) treatment.

The indicator of total pharmaceutical expenditure as a proportion of the total health expenditure ratio within the analyzed period is lower than the indicator of total inpatient expenditure and total health expenditure ratio, which is positive, since it proves the correct pharmaceutical prescriptions. In Poland, the two indicators have almost the same number and are not higher than 33\%. This ratio of indicators, along with $60 \%$ of both indicators as a part of total health expenditure, shows the correct hospital as well as ambulatory treatment of patients.

The crude death rate is 1,000 persons higher in Ukraine and Russia than in Poland. The level of the ratio fluctuates between 13.9-16.7 in Ukraine, between 14.2-16.1 in Russia, 
Table 3. Indicators of health system assessment in Ukraine, Poland and Russia over 20 years

\begin{tabular}{|c|c|c|c|c|c|}
\hline Indicators & 1995 & 2000 & 2005 & 2010 & 2015 \\
\hline \multicolumn{6}{|l|}{ Ukraine } \\
\hline \multicolumn{6}{|l|}{ 1. Product indicators } \\
\hline Estimated life expectancy (years) & $n / a$ & 67.5 & 67.0 & 69.8 & 71.3 \\
\hline Hospitals (per 100,000 persons) & 7.2 & 6.2 & 5.6 & 6.0 & 4.0 \\
\hline Hospital beds (per 100,000 persons) & 1189 & 882 & 868 & 938 & 746 \\
\hline General practitioners (per 100,000 persons) & $\mathrm{n} / \mathrm{a}$ & 26 & 32 & 35 & 36 \\
\hline Physicians (per 100,000 persons) & $\mathrm{n} / \mathrm{a}$ & 300 & 302 & 349 & 350 \\
\hline Proportion of physicians working in hospitals (\%) & $\mathrm{n} / \mathrm{a}$ & 94.7 & 93.9 & 91.7 & 94.1 \\
\hline \multicolumn{6}{|l|}{ 2. Efficiency indicators } \\
\hline Public-sector health expenditure as \% of total health expenditure (WHO estimates) & 72.6 & 51.8 & 59.5 & 56.6 & 50.8 \\
\hline Total inpatient expenditure as a proportion of total health expenditure & 82.0 & 64.0 & 76.7 & 32.6 & $\mathrm{n} / \mathrm{a}$ \\
\hline Total pharmaceutical expenditure as proportion of total health expenditure & 12.0 & 11.6 & 10.7 & 4.2 & $\mathrm{n} / \mathrm{a}$ \\
\hline \multicolumn{6}{|l|}{ 3. Quality indicators } \\
\hline Crude death rate (per 1,000 persons) & 15.5 & 15.4 & 16.7 & 15.3 & 13.9 \\
\hline Acute care hospital discharges (per 100 persons) & 20.8 & 18.4 & 20.5 & 21.9 & 18.4 \\
\hline Average length of stay, acute care hospitals only (number of days) & 14.6 & 12.7 & 11.6 & 10.6 & 9.9 \\
\hline Average length of stay, all hospitals (number of days) & 16.8 & 14.9 & 13.5 & 12.5 & 11.4 \\
\hline \multicolumn{6}{|l|}{ Poland } \\
\hline \multicolumn{6}{|l|}{ 1. Product indicators } \\
\hline Estimated life expectancy (years) & $\mathrm{n} / \mathrm{a}$ & 73.7 & 75.0 & 76.3 & 77.5 \\
\hline Hospitals (per 100,000 persons) & 1.9 & 2.1 & 2.3 & 2.5 & 2.8 \\
\hline Hospital beds (per 100,000 persons) & $\mathrm{n} / \mathrm{a}$ & $\mathrm{n} / \mathrm{a}$ & 652 & 661 & 652 \\
\hline General practitioners (per 100,000 persons) & $\mathrm{n} / \mathrm{a}$ & 8 & 14 & 21 & 22 \\
\hline Physicians (per 100,000 persons) & 232 & 222 & 214 & 219 & 227 \\
\hline Proportion of physicians working in hospitals & $\mathrm{n} / \mathrm{a}$ & 51.8 & 50.3 & $\mathrm{n} / \mathrm{a}$ & $\mathrm{n} / \mathrm{a}$ \\
\hline \multicolumn{6}{|l|}{ 2. Efficiency indicators } \\
\hline Public-sector health expenditure as \% of total health expenditure (WHO estimates) & 72.9 & 70.0 & 69.3 & 71.2 & 71.0 \\
\hline Total inpatient expenditure as proportion of total health expenditure & $\mathrm{n} / \mathrm{a}$ & 29.1 & 29.4 & 32.7 & $\mathrm{n} / \mathrm{a}$ \\
\hline Total pharmaceutical expenditure as proportion of total health expenditure & $\mathrm{n} / \mathrm{a}$ & 28.4 & 28.0 & 22.7 & $\mathrm{n} / \mathrm{a}$ \\
\hline \multicolumn{6}{|l|}{ 3. Quality indicators } \\
\hline Crude death rate (per 1,000 persons) & 10.0 & 9.6 & 9.7 & 9.9 & 10.4 \\
\hline Acute care hospital discharges (per 100 persons) & $\mathrm{n} / \mathrm{a}$ & $\mathrm{n} / \mathrm{a}$ & 13.9 & 15.8 & 16.6 \\
\hline Average length of stay, acute care hospitals only (number of days) & $\mathrm{n} / \mathrm{a}$ & $\mathrm{n} / \mathrm{a}$ & 7.9 & 7.3 & 6.6 \\
\hline Average length of stay, all hospitals (number of days) & $\mathrm{n} / \mathrm{a}$ & $\mathrm{n} / \mathrm{a}$ & 8.2 & 7.6 & 6.9 \\
\hline \multicolumn{6}{|l|}{ Russian Federation } \\
\hline \multicolumn{6}{|l|}{ 1. Product indicators } \\
\hline Estimated life expectancy (years) & $\mathrm{n} / \mathrm{a}$ & 65.0 & 65.0 & 68.4 & 70.5 \\
\hline Hospitals (per 100,000 persons) & 7.8 & 6.9 & 6.2 & 4.0 & 3.5 \\
\hline Hospital beds (per 100,000 persons) & 1187 & 1089 & 974 & 875 & 818 \\
\hline General practitioners (per 100,000 persons) & 41 & 38 & 39 & 52 & 32 \\
\hline Physicians (per 100,000 persons) & 233 & 235 & 233 & 240 & 331 \\
\hline Proportion of physicians working in hospitals & $\mathrm{n} / \mathrm{a}$ & 58.0 & $\mathrm{n} / \mathrm{a}$ & $\mathrm{n} / \mathrm{a}$ & $\mathrm{n} / \mathrm{a}$ \\
\hline \multicolumn{6}{|l|}{ 2. Efficiency indicators } \\
\hline Public-sector health expenditure as \% of total health expenditure (WHO estimates) & 73.9 & 59.9 & 62.0 & 54.1 & 52.2 \\
\hline Total inpatient expenditure as proportion of total health expenditure & 73.6 & $\mathrm{n} / \mathrm{a}$ & $\mathrm{n} / \mathrm{a}$ & $\mathrm{n} / \mathrm{a}$ & $\mathrm{n} / \mathrm{a}$ \\
\hline Total pharmaceutical expenditure as proportion of total health expenditure & $\mathrm{n} / \mathrm{a}$ & 22.0 & 21.0 & $\mathrm{n} / \mathrm{a}$ & $\mathrm{n} / \mathrm{a}$ \\
\hline \multicolumn{6}{|l|}{ 3. Quality indicators } \\
\hline Crude death rate (per 1,000 persons) & 15.0 & 15.4 & 16.1 & 14.2 & $\mathrm{n} / \mathrm{a}$ \\
\hline Acute care hospital discharges (per 100 persons) & 20.2 & 21.2 & 21.4 & 21.5 & 20.6 \\
\hline Average length of stay, acute care hospitals only (number of days) & 13.6 & 13.5 & 11.9 & 10.8 & 9.7 \\
\hline Average length of stay, all hospitals (number of days) & 16.8 & 15.5 & 13.8 & 12.7 & 11.4 \\
\hline
\end{tabular}


and between 9.6-10.4 in Poland. This shows a higher reproductivity in Poland. Moreover, the death rate indicator in Ukraine in 1995 was exceeded only in 2005, and in Poland in 2015. This proves that the living standard and health care advancement influence the population positively in these two countries. In Russia, this ratio was higher than at the base period between 2000-2005, which are assessed more negatively. Usually, the death rate should not be used for international comparison, since it depends on age pattern of the population being compared and can be quite misleading. However, since the countries chosen for the comparison were from highly developed and developed groups, it can be assumed that the age pattern of thepopulation in Ukraine, Poland and Russia has no serious discrepancies.

The indicator of acute care hospital discharges (100 persons) can be assessed from two sides. Since the acute care hospitals are aimed at decreasing disease severity (injuries), acute exacerbation or complication from illness (injuries) that may threaten the life and health of the patient. The increase in discharged patients from acute care hospitals shows that the doctors achieved their goal. Statistics shows that for the period being analyzed, in Poland and Russia these indicators are higher than their base value, whereas in Ukraine the indicator exceeded the base value (1995) only in 2010. On the other hand, the decrease in patients discharged from the acute care hospitals can be seen as the lower number of patients checked into the unit, as well as fatal cases, which deserves negative assessment.

Assessment of the average length of stay in acute care hospitals, compared to the average number of days spent in all other units of hospitals, shows that in Ukraine and Poland patients spend less time in the acute care hospitals compared to time spent in other hospitals of the country. Moreover, every year the number of days spent in the hospitals of these two countries drops, which proves advancements in health care. In Russia, however, the tendency is the reverse - an average number of days spent in the acute care hospitals are higher than the average number of days spent in other hospital units. The tendency to shorten the time patients spend in hospitals for the last 20 years, however, is positive and proves proper organization of the treatment process.

In economic books there are a lot of methods for competitiveness assessment [26]. although considering the statistical data gathered, the ranking method will be the most successful for assessing the competitive position of the leading country among the given performance results of health facilities in Ukraine, Poland and Russia. The method allows comparison of the assessment with a group of companies-rivals, and to identify its place in the competition, as well as to predict factors leading to success. The method is quite simple and does not require thorough mathematical calculations. Assessing indicators can be economically varied units of measurement, which should be ranked considering the rules identical for all indicators. Maximum ranking (1) will be given to those countries that have the highest values for the period analyzed, consequently, rank three will be given to the country which has the lowest indicator.

Thus, every key indicator (Tab. 3) will be ranked among the three participating countries. For the researched period, the last described period (2015) was selected from Table 3. Indicators which did not contain factual data in any of the countries, were not included into the ranking. The result of calculations is shown in Table 4.
Table 4. Ranking of indicators for health care system efficiency assessment in Ukraine, Poland and Russia in 2015.

\begin{tabular}{|c|c|c|c|}
\hline Indicators & Ukraine & Poland & $\begin{array}{l}\text { Russian } \\
\text { Federation }\end{array}$ \\
\hline \multicolumn{4}{|l|}{ 1. Product indicators } \\
\hline Estimated life expectancy (years) & $\frac{71,3}{2}$ & $\frac{77,5}{1}$ & $\frac{70,5}{3}$ \\
\hline Hospitals (per 100,000 persons) & $\frac{4,0}{1}$ & $\frac{2,8}{3}$ & $\frac{3,5}{2}$ \\
\hline Hospital beds (per 100,000 persons) & $\frac{746}{2}$ & $\frac{652}{1}$ & $\frac{818}{3}$ \\
\hline General practitioners (per 100,000 persons) & $\frac{36}{1}$ & $\frac{22}{3}$ & $\frac{32}{2}$ \\
\hline Physicians (per 100,000 persons) & $\frac{350}{1}$ & $\frac{227}{3}$ & $\frac{331}{2}$ \\
\hline \multicolumn{4}{|l|}{ 2. Efficiency indicators } \\
\hline $\begin{array}{l}\text { Public-sector health expenditure as \% of total } \\
\text { health expenditure (WHO estimates) }\end{array}$ & $\frac{50,8}{3}$ & $\frac{71,0}{1}$ & $\frac{52,2}{2}$ \\
\hline \multicolumn{4}{|l|}{ 3. Quality indicators } \\
\hline Acute care hospital discharges (per 100 persons) & $\frac{18.4}{2}$ & $\frac{16.6}{1}$ & $\frac{20.6}{3}$ \\
\hline $\begin{array}{l}\text { Average length of stay, acute care hospitals only } \\
\text { (number of days) }\end{array}$ & $\frac{9.9}{3}$ & $\frac{6.6}{1}$ & $\frac{9.7}{2}$ \\
\hline $\begin{array}{l}\text { Average length of stay, all hospitals } \\
\text { (number of days) }\end{array}$ & $\frac{11.4}{2}$ & $\frac{6.9}{1}$ & $\frac{11.4}{2}$ \\
\hline Total summary of places & 17 & 15 & 21 \\
\hline Total ranking position & 2 & 1 & 3 \\
\hline
\end{tabular}

Source: independently processed

Therefore, the data, analyzed in Table 4, allow the decision that, considering the number of key indicators for the health care system competitiveness level, the leading country is Poland, based on the criteria of minimum position score, Ukraine takes the second (medium) place for the health care system competitiveness level. The outsider is Russia. The major positive role in leadership for Poland was played by the efficiency and quality indicators. The biggest problems among the analyzed groups of the Russian health care system were product indicators.

\section{CONCLUSIONS}

Competitiveness of national health facilities is defined by their ability to rationally and efficiently allocate the funding resources for target-oriented health care programmes (budgetary and extra-budgetary). This depends on funding efficiency, development of a proper internal audit system for achieving efficiency indicators, as regulated in the budget programme brief.

Today, assessment of the activities of Ukrainian medical institutions may be carried out by using a system of effective indicators for the implementation of State target programmes, approved for such institutions by the Ministry of Finance and the Ministry of Health within the brief for the budget programme. The combination of these indicators is divided into four basic groups: cost indicators, product indicators, efficiency indicators, and quality indicators. However, the analysis showed that nowadays, in the current reporting forms, such indicators, unfortunately, are not widely published, which makes it impossible to carry out 
a comprehensive assessment of their activities. This is due to the lack of appropriate reporting forms, insufficient attention of the Ministry of Health of Ukraine to unify the method of completing them.

The research has shown that it is expedient to conduct an analytical assessment of the performance indicators of medical institutions, not only on the domestic market; an assessment of the efficiency of health systems in different countries is also important for disseminating progressive experience.

In conclusion, the following recommendations are suggested:

1. Implementing integrated reporting, which will allow identification of the relationship between financial indicators and the results of management of social, environmental and economic activities; generalize the evaluation of the effective indicators of the implementation of state medical target programmes as one of the important factors for the competitiveness of direct medical institutions.

2. Ensuring the transparency and objectivity of data on the performance of efficiency indicators, the effective use of relevant information for calculating the profitability indicators, acceleration of completion of the modernization of the records of domestic medical institutions in Ukraine (within the framework of the pre-adopted State Strategy) on the principles of International Public Sector Accounting Standards.

3. According to the results of the comparative analysis of the competitiveness indicators of health care systems in Ukraine, Poland and Russia, it has been established that Ukraine ranks as an intermediate in second place as an alternative. It is proposed that at State level, Ukraine should pay attention to indicators that are not high enough in comparison with the leading positions of the Polish health system, namely, indicators of efficiency and quality.

4. The most important factors for providing reliable accounting data for allocating budget funding (i.e. health care competitiveness assessment) and analysis of health care system performance are as follows:

- controlling previously approved efficiency indicators at every stage of budget programme performance, public discussion and disclosure of the achieved efficient indicators via the media;

- developing a system for continuing professional training for accounting and analytical staff (bookkeepers, economists, internal controllers, etc.) working in health facilities;

- developing a standard form of integrated reporting by the results of the State health care programme, and obligatory regular monitoring and analysis of health care systems along with the level of competitiveness of health facilities. The total number of all indicators analyzed is quite flexible and can be expanded due to strategic goals of health facility development. It is crucial to monitor the situation in the region and to define individual positions of the market of medical services. The tendencies of global market health facilities should also be taken into considered. This will enable not only proper caring for health and the national living standard, but will also give access to the single medical services market due to health tourism. This will be an excellent opportunity to develop national medicine which would also add to the national treasury.

\section{REFERENCES}

1. Kister A. Causes and sources of hidden costs in a medical facility. Revue de Management et de Stratégie. 2014; 11(2): 14-25.

2. Bengtsson M, Hinttu S, Kock S. Cooperation and competition in relationships between competitors in business networks. Journal of Business \& Industrial Marketing. 1999; 14 (3): 178-194.

3. Bloom N, Propper C, Seiler S, Reenen JV. The Impact of Competition on Management Quality: Evidence from Public Hospitals. 2010; CEP Discussion Paper N 983.

4. Hamel G, Prahalad CK. [Competitive advantage of tomorrow. Strategies of taking control over the industry and creating markets of the future]. Warsaw: Business Press; 1999.

5. Kanownik G. [An integrated model of competitiveness in health care on the example of district hospitals] [dissertation]. Mount Pleasant (MI): Warsaw School of Economics; 2016.

6. Obłój K. [Strategy of organization. In search of a lasting competitive advantage]. Warsaw: Polish Economic Publisher; 2007.

7.Sygit K, Sygit M, Grzybowska A. Managing through cooperation between doctors and patients in health care and health promotion. Entrepreneurship and Management. 2017; 18: 71-87.

8. Tyszko P, Wierzba WM, Kanecki K, Ziółkowska A. Transformation of the ownership structure in Polish Healthcare and its effects. Central and European Journal of Medicine. 2007; 2(4): 528-538.

9. Tohunov IA. Competition in health care and medicine. Health service manager. 2005; 12: 12-21.

10. Rotaub R. [Free choice, competition and regulations]. Health Market. 2011 Aug 16; Sect. Health policy.

11. Porter ME. Redefining Health Care: Creating Value-Based Competition on Results. https://www.hbs.edu/faculty/Publication\%20 Files/20060502\%20NACDS\%20-\%20Final\%2005012006\%20for\%20 On\%20Point_db5ede1d-3d06-41f0-85e3-c11658534a63.pdf (access: 2018.08.12).

12. On approval of typical enumeration of budget programmes and their efficient performance indicators in health care field of local budgets, Joint decree of Ministry of Finance and Ministry of Health of Ukraine. No. 693/633 (July 25, 2013).

13. Bernaz-Lukavetska OM. Medical services in Ukraine. http://jurist-blog. com.ua/medichni-poslugi.html (access: 2018.03.15).

14. Fedosov VM, Yurii SI. Budget system. Tsentr uchbovoi literatury (Kyiv) Publishers; Ekonomichna dumka (Ternopil) Publishers, 2012.

15. Kostiuchenko VM, Bohatyr NV. Integrated reporting as innovative model of reporting in Ukrainian corporate enterprises. http://globalnational.in.ua/archive/8-2015/236.pdf (access: 2018.03.15).

16. Concept of special-purpose programme in budgeting, Resolution of the Cabinet of Ministers of Ukraine. No. 538-p. (Sept 14, 2002).

17. Stankus T. Special-purpose programme in budgeting process of local budgets. Faktor (Kharkiv) Publishers, 2017.

18. On approval of Strategy for accounting system modernisation in public sector for 2007-2015, Decree of Cabinet of Ministers of Ukraine. No. 34 (Jan 16, 2007).

19. On approval of the National Public Sector Accounting Standards in the public sector 124 "Revenues", Ministry of Finance of Ukraine Order. No. 1629 (Dec 24, 2010).

20. On approval of the National Public Sector Accounting Standards in the public sector 123 "Inventories", Ministry of Finance of Ukraine Order. No. 1202 (Oct 12, 2010).

21. On approval of the National Public Sector Accounting Standards in the public sector 135 "Expenditure", Ministry of Finance of Ukraine Order. No. 568 (May 18, 2012).

22. On approval of the National Public Sector Accounting Standards in the public sector 101 "Preparing financial reporting", Ministry of Finance of Ukraine Order. No. 1541. (Dec 28, 2009).

23. On approval of the National Public Sector Accounting Standards in the public sector 121 "Fixed assets", Ministry of Finance of Ukraine Order. No. 1202. (Oct 12, 2010).

24. European Health for All Database [Internet]. Copenhagen: WHO Regional Office for Europe. [access: 2018 Mar 25]. Available from: http://www.euro.who.int/ru/data-and-evidence/databases/europeanhealth-for-all-family-of-databases-hfa-db.

25. Beztelesna LI, Pyvovarchuk LV. Institutional provision of state social guarantees implementation. Kondor (Kyiv) Publishers, 2017.

26. Michalczyk L. Wielokryterialna analiza czynników strategii konkurencyjnej banków na przykładzie wybranych oddziałów banków małopolskich. Handel Wewnętrzny. 2012; 339(4): 91-106. 


\title{
Konkurencyjność instytucji medycznych: podejście rachunkowe i analityczne
}

\author{
Streszczenie \\ Cel pracy. Celem artykułu jest zbadanie sprawozdań ukraińskich instytucji medycznych na temat wskaźników zatwierdzonych \\ w paszportach dedykowanych programów budżetowych, a także określenie poziomu konkurencyjności systemu opieki \\ zdrowotnej Ukrainy w porównaniu z systemami opieki zdrowotnej Polski i Rosji z wykorzystaniem ww. wskaźników. \\ Materiał i metody. Jako materiały badawcze wykorzystano akty prawne, a także dane statystyczne uzyskane z europejskiej \\ bazy danych „Zdrowie dla wszystkich". Za główne metody badawcze uznano metodę opisową, uogólnienia, rangowania \\ oraz metody analizy systemowej, porównawczej i statystycznej. \\ Wyniki. Badając poziom konkurencyjności systemu opieki zdrowotnej, ustalono, że najwyższe wskaźniki według kryterium \\ punktów minimalnych miała Polska. W dalszej kolejności jest Ukraina, a następnie Rosja. W Polsce kluczową rolę odgrywają \\ wskaźniki efektywności i jakości. Dla Rosji najniższe wartości przyjmowały wskaźniki produktów.

\section{Wnioski:} \\ 1) Zaleca się wdrożenie zintegrowanej sprawozdawczości, która posłuży jako źródło analizy przydatnej do oceny wskaźników \\ wykonania rządowych programów docelowych oraz poziomu konkurencyjności poszczególnych zakładów opieki zdrowotnej. \\ 2) Konieczne jest przeprowadzenie reformacji rachunkowości krajowych jednostek medycznych (w ramach państwowej \\ polityki), opierając się na zasadach prowadzenia rachunkowości zgodnie ze standardami rachunkowości w sektorze \\ publicznym. \\ 3) Na poziomie państwowym Ukraina powinna zwrócić uwagę na wskaźniki, które nie są wystarczająco wysokie w porównaniu \\ ze wskaźnikami polskiego systemu opieki zdrowotnej - wskaźnikami efektywności oraz jakości.
}

\section{Słowa kluczowe}

konkurencyjność instytucji medycznych, działalność zakładów opieki zdrowotnej, sprawozdawczość zintegrowana, analiza i ocena poziomu konkurencyjności, rankingowanie wskaźników 